\title{
The superficial ulnar artery: development and clinical significance
}

\author{
Artéria ulnar superficial: desenvolvimento e relevância clínica
}

\author{
Srinivasulu Reddy ${ }^{1}$, Venkata Ramana Vollala ${ }^{2}$
}

\begin{abstract}
The principal arteries of the upper limb show a wide range of variation that is of considerable interest to orthopedic surgeons, plastic surgeons, radiologists and anatomists. We present here a case of superficial ulnar artery found during the routine dissection of right upper limb of a 50-year-old male cadaver. The superficial ulnar artery originated from the brachial artery, crossed the median nerve anteriorly and ran lateral to this nerve and the brachial artery. The superficial ulnar artery in the arm gave rise to a narrow muscular branch to the biceps brachii. At the elbow level the artery ran superficial to the bicipital aponeurosis where it was crossed by the median cubital vein. It then ran downward and medially superficial to the forearm flexor muscles, and then downward to enter the hand. At the palm, it formed the superficial and deep palmar arches together with the branches of the radial artery. The presence of a superficial ulnar artery is clinically important when raising forearm flaps in reconstructive surgery. The embryology and clinical significance of the variation are discussed.
\end{abstract}

Keywords: Upper limb, superficial ulnar artery, brachial artery, forearm flexor muscles, forearm flaps.

\section{Introduction}

Normally, the ulnar artery begins distal to the bend of the elbow as the larger of the two terminal divisions of the brachial artery. It runs deep to the antebrachial flexor muscles and then superficial to the flexor retinaculum. The artery ends by forming the superficial palmar arch with a contribution from the superficial branch of the radial artery. The arch gives palmar digital branches to the medial three fingers and also to the medial half of the index finger. The lateral aspect of the index finger and the thumb normally receive their arterial supply from the radial artery through the radialis indicis and the princeps pollicis arteries, respectively. ${ }^{1}$

The term superficial ulnar artery is applied to an artery which arises from the axillary, brachial or superficial brachial arteries and courses over the origins of

\section{Resumo}

As principais artérias do membro superior apresentam uma ampla variação, que é relativamente importante a cirurgiões ortopédicos e plásticos, radiologistas e anatomistas. Apresentamos um caso de artéria ulnar superficial encontrada durante dissecção de rotina de membro superior direito de um cadáver masculino de 50 anos de idade. A artéria ulnar superficial originava-se da artéria braquial, cruzava o nervo mediano anteriormente e percorria lateralmente esse nervo e a artéria braquial. A artéria ulnar superficial no braço deu origem a um ramo muscular estreito do músculo bíceps braquial. Ao nível do cotovelo, a artéria percorria superficialmente a aponeurose bicipital, onde era cruzada pela veia cubital mediana. Percorria, então, em sentido descendente e medialmente superficial aos músculos flexores do antebraço, e então descendia para entrar na mão. Na palma, essa artéria formava os arcos palmares superficial e profundo junto com os ramos da artéria radial. A presença de uma artéria ulnar superficial é clinicamente importante ao levantar retalhos do antebraço em cirurgias reconstrutivas. A embriologia e relevância clínica da variação são discutidas.

Palavras-chave: Membro superior, artéria ulnar superficial, artéria braquial, músculos flexores do antebraço, retalhos do antebraço.

the superficial forearm muscles to join at the midlevel of the forearm with the ulnar artery, sometimes replacing it..$^{2-4}$ Its incidence ranges from $0.7^{5}$ to $3.3 \% .^{6}$ The superficial ulnar artery has been reported with different terminologies; arteria antebrachialis superficialis ulnaris, ${ }^{5-7}$ high origin of the ulnar artery ${ }^{8,9}$ and superficial ulnar artery with a high origin. ${ }^{10}$

\section{Case report}

The superficial ulnar artery (Figures 1 and 2) was found in the right upper limb of a 50 -year-old male cadaver during routine dissections in the Melaka Manipal Medical College, Manipal, India. However, the left upper limb showed no abnormalities. The dissections of both upper extremities (right and left) of the

1. Department of Anatomy, KMC International Centre, Manipal, India.

2. Department of Anatomy, Melaka Manipal Medical College (Manipal Campus), International Centre for Health Sciences, Manipal, India.

Manuscript received May 1st, 2007, accepted June 08, 2007.

J Vasc Bras 2007;6(3):285-288.

Copyright $\odot 2007$ by Sociedade Brasileira de Angiologia e de Cirurgia Vascular 
body were carried out according to the instructions by Cunningham's manual of practical anatomy. The dissections took place during 2005-2006. The bodies were preserved by the injection of a formalin-based preservative $\left(10 \%\right.$ formalin) and stored at $-4^{\circ} \mathrm{C} .{ }^{12}$

\section{Discussion}

The superficial ulnar artery is a well-known but very rarely encountered abnormality. In the present case the artery arose from the brachial artery in the proximal part of the arm. It then descended along the arm superficial and lateral to the median nerve (Figure 1). At the elbow level the artery ran superficial to the bicipital aponeurosis where it was crossed by the median cubital vein (Figure 1). After that, the artery coursed obliquely downwards and medially, superficial to the forearm flexor muscles over the antebrachial fascia and under the superficial venous system to reach the distal third of the forearm, where it was seen on the lateral side of flexor carpi ulnaris close to the ulnar nerve (Figure 2). The artery then passed anterior to the flexor retinaculum where it divided into two terminal branches. The superficial one anastomosed with the palmar branch of the radial artery to form the superficial palmar arch and the deep branch anastomosed with the radial artery to form the deep palmar arch.

The brachial artery had a normal course in the arm but at elbow level it divided into the radial and common interosseous arteries (Figure 2). The superficial ulnar artery was of a smaller caliber than both the radial and common interosseous arteries.

The superficial course of the ulnar artery over the forearm flexors has been described in two ways: under the antebrachial fascia ${ }^{8,11-13}$ or, more infrequently, as in our case, over the antebrachial fascia in a subcutaneous position, ${ }^{11,14}$ crossed by the median cubital vein. ${ }^{15}$ The artery has been described as gaining the lateral border of flexor carpi ulnaris at midforearm level ${ }^{12}$ or after passing deep to the palmaris longus. ${ }^{11,12,16,17}$ However, in our case this relationship was gained at the distal third of the forearm, close to the wrist joint. Our case was not associated with other arterial anomalies, although other authors have reported superficial ulnar artery associated with the presence of a median artery. $8,16,18$

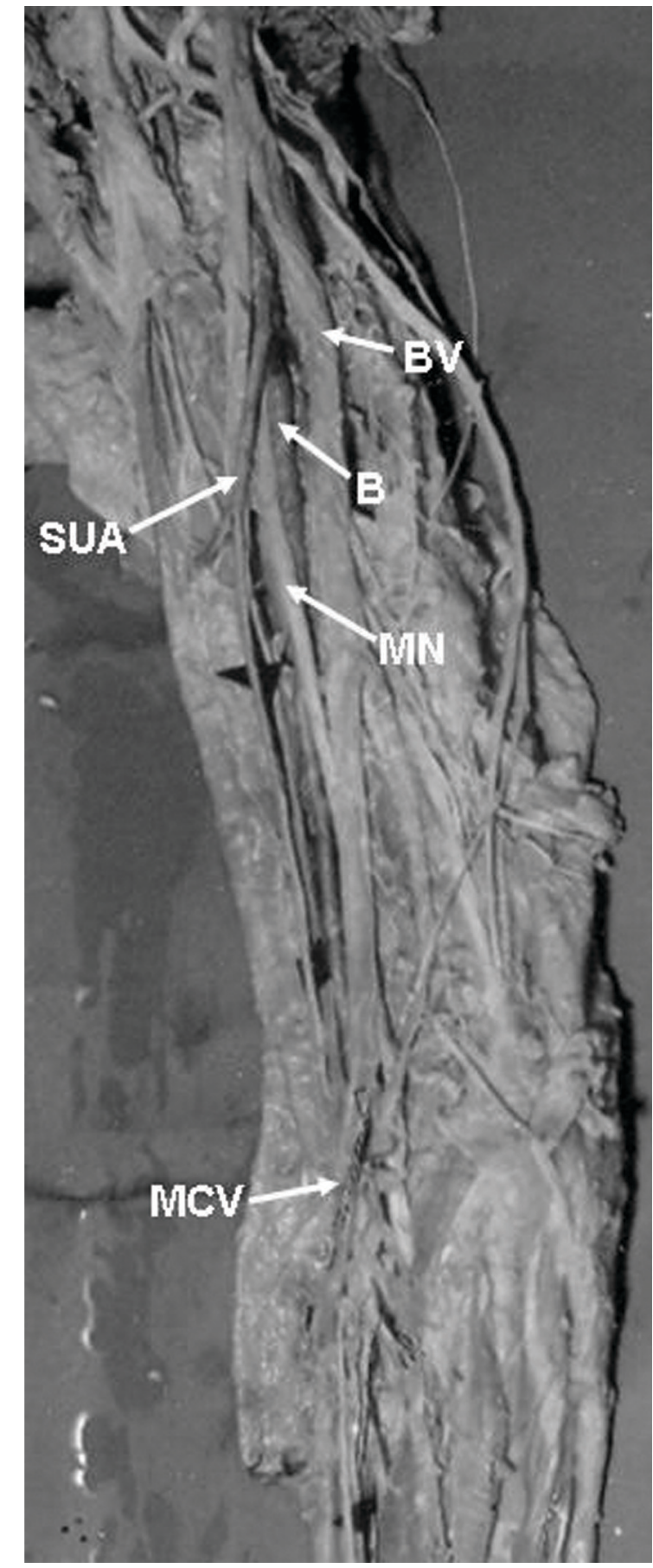

$\mathrm{B}=$ brachial artery; $\mathrm{BV}=$ basilic vein $; \mathrm{MCV}=$ median cubital vein; $\mathrm{MN}=$ median nerve; $\mathrm{SUA}=$ superficial ulnar artery

Figure 1 - Right arm with superficial ulnar artery

Developmentally, the upper limb bud is initially supplied by a vascular plexus derived from four or five consecutive intersegmental branches of the dorsal aorta. 


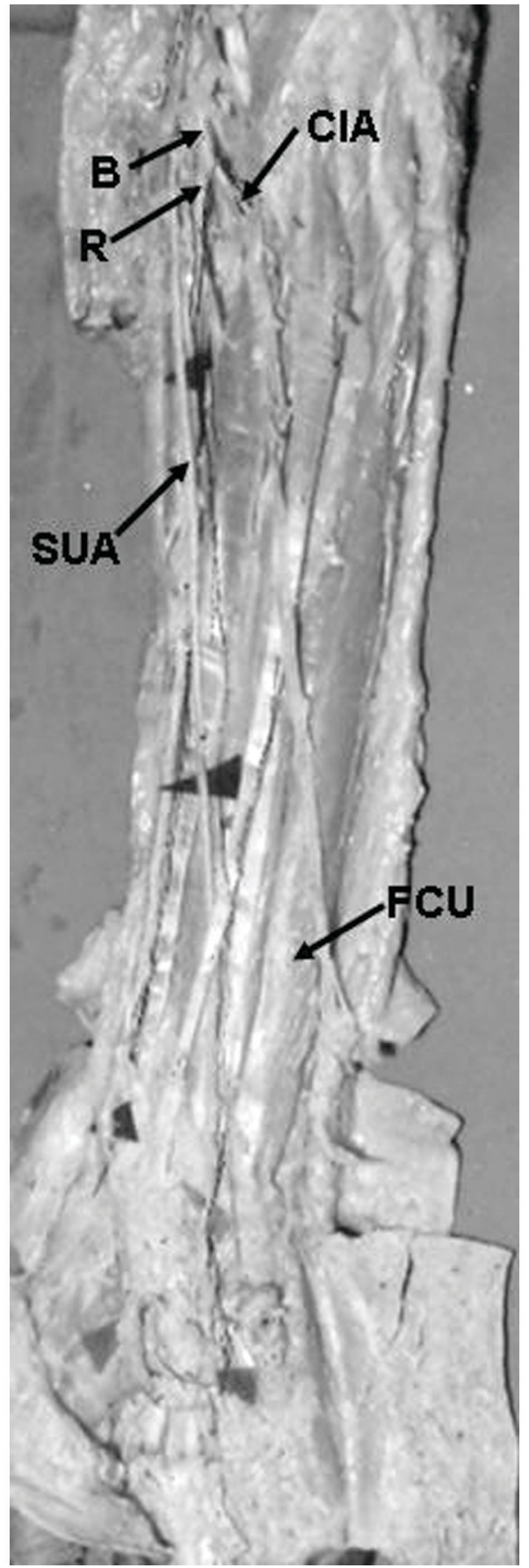

$\mathrm{B}=$ brachial artery CIA $=$ common interosseous artery FCU $=$ flexor carpi ulnaris; $\mathrm{R}=$ radial artery; SUA = superficial ulnar artery

Figure 2 - Superficial course of the artery along the forearm

Very early in development, the seventh cervical intersegmental branch enlarges and becomes consolidated as the main artery (axis artery) to the developing upper limb bud. This axis artery gives rise to the subclavian, axillary, brachial, and interosseous arteries and to the deep palmar arch. Other arteries of the upper limb develop as sprouts of the axis artery. ${ }^{19-22}$ The developmental reason for the superficial ulnar artery in the present case may be due to the ulnar artery establishing a connection with the axis artery in the arm and the bifurcation of brachial artery into radial artery and common interosseous artery may be due to the posterior interosseous artery arising from the axis artery just distal to the connection of radial artery with the axis artery in the cubital fossa region and the continuation of the main trunk (axis artery) between radial and posterior interosseous arteries being the common interosseous artery.

Vascular anomalies occurring in common surgical sites tend to increase the likelihood of damage during surgery. Owing to its unusual origin in the arm and its subcutaneous course, the superficial ulnar artery would be particularly vulnerable in surgical procedures within the arm and forearm. In the present subject the ulnar artery was immediately subjacent to the median cubital vein. This would predispose the vessel to inadvertent penetration during attempts at venipuncture of the median cubital vein.

Although accidental intra-arterial injection of drugs is rare, if it occurs, amputation of the forearm or fingers is unfortunately sometimes necessary. Since the free forearm flap on the radial artery is often used in reconstructive surgery, if a superficial ulnar artery is present there is a risk that it may be ligated or cut instead of the superficial vein, causing disorder of circulation in the hand. ${ }^{11,23}$ On the other hand, the presence of a superficial ulnar artery can be advantageous, since it can be used to supply blood to the forearm flap. ${ }^{24}$ Radiographically, the superficial ulnar artery can lead to misinterpretation of incomplete angiographic pictures. ${ }^{23}$ Therefore, it is important to know whether a patient has a superficial ulnar artery in the forearm.

\section{Conclusion}

Since a superficial ulnar artery is actually not very rare, there is a fair chance that clinicians may encounter 
this anomaly. Therefore, one should always keep in mind this anatomic variation and try to detect it before any technical procedure in the upper limb. Owing to its surgical importance, variations of the ulnar artery merit description.

\section{References}

1. Hollinshead WH. Anatomy for surgeons. 2nd ed. New York: Harper \& Row; 1971. Vol. 3. The back and limbs.

2. Lippert H, Pabst R. Arterial variations in man. Munchen: JF Bergmann; 1985. p. 71-3.

3. Nakatani T, Tanaka S, Mizukami S, Shiraishi Y, Nakamura T. The superficial ulnar artery originating from the axillary artery. Ann Anat. 1996;178:277-9.

4. Nakatani T, Tanaka S, Mizukami S. Superficial brachial artery continuing as the common interosseous artery. J Anat. 1997;191(Pt 1):155-7.

5. Adachi B, Hasebe K. Das Arteriensystem der Japaner. Kyoto: Maruzen; 1928. Vol. 1. p. 338-74.

6. Muller E. Beitrage zur Morphologie des Gefässytstems. I. Die Armarterien des Menschen. Anat Hefte. 1903;22:377-575.

7. Gruber W. Ueber die Arteria mediana antibrachii superficialis, Arteria ulnaris antibrachii superfcialis und Duplicitat der Arteria ulnaris. Archiv Anat Physiol. 1867;668-87.

8. Rodriguez-Baeza A, Nebot J, Ferreira B, et al. An anatomical study and ontogenic explanation of 23 cases with variations in the main pattern of the human brachio-antebrachial arteries. J Anat. 1995; 187(Pt 2):473-9.

9. Aharinejad S, Nourani F, Hollensteiner H. Rare case of high origin of the ulnar artery from the brachial artery. Clin Anat. 1997; 10:253-8.

10. Fuss FK. Uber eine Arteria ulnaris superficialis mit hohem Ursprung und atypischer Lage. Gegenbaurs Morphol Jahrb. 1988;134:215-20.

11. Hazlett JW. The superficial ulnar artery with reference to accidental intra-arterial injection. Can Med Assoc J. 1949;61:289-93.

12. McCormack LJ, Cauldwell EW, Anson BJ. Brachial and antebrachial arterial patterns; a study of 750 extremities. Surg Gynecol Obstet. 1953;96:43-54.
13. Anil A, Turgut HB, Peker TV. A variant of superficial ulnar artery. Surg Radiol Anat. 1996;18:237-40.

14. Quain R. Anatomy of the arteries of the human body. London: Taylor \& Walton; 1844. p. 326-37.

15. Fadel RA, Amonoo-Kuofi HS. The superficial ulnar artery: development and surgical significance. Clin Anat. 1996;9:128-32.

16. Schwyzer AG, de Garis CF. Three diverse patterns of the arteria brachialis superficialis in man. Anat Rec. 1935;63:405-16.

17. Weathersby HT. Anomalies of brachial and antebrachial arteries of surgical significance. South Med J. 1956;49:46-9.

18. Pabst R, Lippert H. Beiderseitiges Vorkommen von A. brachialis superficialis, A. ulnaris superficialis und A. mediana. Anat Anz. 1968;123:223-6.

19. Arey LB. Arteries of the limbs. In: Arey LB. Developmental anatomy. 7th ed. Philadelphia: WB Saunders; 1966. p. 358-9.

20. Patten BM. Arteries of the extremities. In: Patten BM. Human embryology. 3rd ed. New York: McGraw Hill; 1968. p. 518-21.

21. Allan FD. Arteries of the extremities. In: Allan FD. Essentials of human embryology. 2nd ed. London: Oxford; 1969. p. 97.

22. Hamliton WJ, Mossman HW. Arteries of the limb buds. In: Hamilton WJ, Boyd JD \& Mossman HW. Hamilton, Boyd and Mossman's Human exmbryology. 4th ed. Cambridge: W Heffer \& Sons; 1972. p. 208-9; 271.

23. Poteat WL. Report of a rare human variation: Absence of the radial artery. Anat Rec. 1986;214:89-95.

24. Devansh MS. Superficial ulnar artery flap. Plast Reconstr Surg. 1996;97:420-6.

Correspondence:
Venkata Ramana Vollala
Lecturer, Department of Anatomy
Melaka Manipal Medical College (Manipal Campus)
International Centre for Health Sciences
Manipal-576104
Karnataka State, India
Tel.: + 91820292.2642
Fax: + 91820257.1905
E-mail: ramana.anat@gmail.com

